\title{
The Currency of Ideas
}


A volume in the series

Cornell Studies in Political Economy edited by Peter J. Katzenstein

A complete list of titles in the series appears at the end of this book. 


\title{
The Currency of Ideas
}

Monetary Politics in the

\author{
EUROPEAN UNION
}

\author{
Kathleen R. McNamara
}

Cornell University Press

Ithaca and London 


\section{Copyright $\mathbb{C} 1998$ by Cornell University}

All rights reserved. Except for brief quotations in a review, this book, or parts thereof, must not be reproduced in any form without permission in writing from the publisher. For information, address Cornell University Press,

Sage House, $5_{1} 2$ East State Street, Ithaca, New York $14^{8} 5$.

First published 1998 by Cornell University Press

First printing, Cornell Paperbacks, 1999

Printed in the United States of America

Cornell University Press strives to use environmentally responsible suppliers and materials to the fullest extent possible in the publishing of its books. Such materials include vegetable-based, low-VOC inks and acid-free papers that are also recycled, totally chlorine-free, or partly composed of nonwood fibers.

Library of Congress Cataloging-in-Publication Data

McNamara, Kathleen R., 1962-

The currency of ideas : monetary politics in the European Union / Kathleen R. McNamara.

p. $\mathrm{cm}$. - (Cornell studies in political economy)

Includes index.

ISBN 978-0-8014-8602-9 (pbk. : alk. paper)

1. Money-European Union countries. 2. Monetary unions-European

Union countries. 3. Monetary policy-European Union countries.

I. Title. II. Series.

$\mathrm{HG}_{92} \mathrm{M}_{3} 8 \quad 1998$

$33^{2.4} \mathbf{4}^{\prime} 94-\mathrm{dc} 21$

$97-29728$

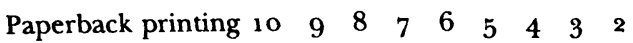


For Theo 
